\title{
FAKTOR - FAKTOR YANG BERHUBUNGAN DENGAN PENYAKIT TBC PADA NELAYAN DI KAMPUNG NELAYAN SEBERANG LINGKUNGAN XII, KELURAHAN BELAWAN I, MEDAN
}

\author{
Fithri Handayani Lubis¹, Rizka Annisa²,
}

Institut Kesehatan Deli Husada Delitua

Jl. Besar Deli No. 77 Deli Tua Kab. Deli Serdang - Sumatera Utara 20355

E-mail : fithri.handa@gmail.com

DOI : https://doi.org/10.35451/jkg.v2i1.277

\begin{abstract}
The objective of the research was to analyze the influence of the characteristics of fishermen's house on the incidence of pulmonary tuberculosis. The research used an analytic method with case-control design. The population was 90 fishermen, wih sample details 45 case and 45 control, taken by using consecutive sampling technique. The data were gathered by conducting interviews, questionnaires, observation, and measurement and analyzed by using univatriate analysis, bivatriate analysis, and multivatriate analysis at the significance level of $95 \%$. The results of the study indicate that there is a relationship between variabel temperature ( $p$-value :0,004), humidity ( $p$-value : 0,006$)$ and mosquito coils ( $p$-value : 0,044 with the incidence of pulmonary tuberculosis. Humidity variable has the highest Exp Value $(B)=8.4$, so it assumed respondents who live in homes with not requirements humidity levels 8.4 times more easily infected with TBC. Kampung nelayan residents are expected to wear warm clothing at night and open windows every day. It is expected that Puskesmas Belawan will implement health program policies set by the government in reducing the incidence of pulmonary tuberculosis.
\end{abstract}

Keywords : Condition of the house, the incidence of pulmonary tuberculosis, fisherman

\section{Pendahuluan}

Sebagai sebuah negara maritim, Nelayan masih menjadi profesi yang masih sangat banyak dijalani oleh masyarakat Indonesia. Besarnya jumlah penduduk Indonesia yang berprofesi sebagai nelayan sejalan dengan munculnya wilayah pemukiman di sepanjang pinggiran laut dangkal yang sering juga disebut dengan Kampung Nelayan. Pemukiman ini memudahkan akses nelayan untuk bekerja di laut dan menyimpan hasil tangkapan laut, sehingga menjadi alternatif yang sering dipilih oleh nelayan. (Lubis, 2015).

Jumlah kematian akibat penyakit infeksi diperkirakan oleh WHO

akan meningkat dari 2,5 juta menjadi 3,5 juta pada tahun 2020. Peningkatan secara pesat jumlah penduduk dunia terutama di negara yang sedang berkembang menyebabkan tingginya tingkat penyebaran penyakit infeksi terutama penyebaran virus HIV dan Tuberkulosis. Belum ditemukannya alternatif penyembuhan maupun 
pencegahan HIV mengisyaratkan bahwa peningkatan kematian akibat infeksi ini hanya dapat diberhentikan bila banyak negara- negara menyelenggarakan penanggulangan Tuberkulosis yang efektif (Crofton, dkk, 2018).

Prevalensi penduduk Indonesia yang didiagnosis TB paru oleh tenaga kesehatan tahun 2013 adalah 0.4 persen, tidak berbeda dengan 2007. Lima provinsi dengan TB paru tertinggi adalah Jawa Barat $(0.7 \%)$, Papua $(0.6 \%)$, DKI Jakarta $(0.6 \%)$, Gorontalo $(0.5 \%)$, Banten $(0.4 \%)$ Papua Barat $(0.4 \%)$ dan Prevalensi Sumatra Utara (0.2\%). (Riskesdas : 2013).

Di Provinsi Sumatera Utara pada tahun 2012 diperkirakan kasus TBC paru sebanyak 22,360 jiwa. Dan pada tahun 2016 diperkirakan kasus TBC sebanyak 17,798 jiwa. (Dinas Kesehatan Provinsi Sumatera Utara : 2016).

Pada tahun 2015 diperkirakan terdapat 10,4 juta kasus baru TBC atau 142 kasus/100.000 populasi, dengan 480.000 kasus multidrug-resistant. Indonesia merupakan negara dengan jumlah kasus baru terbanyak kedua di dunia setelah India. Banyak faktor yang memungkinkan menjadi penyebab pesatnya pertumbuhan kasus TBC di Indonesia, salah satunya adalah realita Indonesia sebagai negara maritim. Besarnya jumlah penduduk Indonesia yang bekerja sebagai nelayan secara langsung menyebabkan tingginya kebutuhan akan tempat tinggal bagi nelayan, sehingga para nelayan mulai mencari daerah alternatif yang dapat dijadikan tempat tinggal, tidak sedikit masyarakt yang berprofesi sebagai nelayan tersebut mulai mendirikan pemukiman di atas permukaan laut dengan alasan untuk memudahkan proses penangkapan ikan, namun disisi lain kondisi lingkungan fisik rumah di pemukiman nelayan yang tidak memenuhi syarat kesehatan inilah yang dapat menjadi salah satu faktor resiko sumber penularan penyakit TBC. (Riskesdas : 2016).

\section{METODE PENELITIAN}

Jenis penelitian ini adalah penelitian analitik dengan desain case control yang bertujuan untuk menganalisis faktor - faktor yang berhubungan dengan Penyakit TBC pada Nelayan.

Populasi kasus dalam penelitian ini adalah Nelayan yang bertempat tinggal di Kampung Nelayan Seberang Lingkungan XII, Keluran Belawan I, Medan dan populasi kontrol adalah Nelayan yang bertempat tinggal di Desa Young Panah Hijau, Kelurahan Belawan, Medan.

Pemilihan lokasi populasi kasus didasarkan pada pertimbangan bahwa di pemukiman nelayan tersebut merupakan pemukiman yang berdiri di atas permukaan air laut dan dilokasi tersebut ditemukan masalah yang sedang diteliti sedangkan pemilihan lokasi populasi kontrol karena lokasi berdekatan dengan lokasi populasi kasus, namun memiliki karakteristik pemukiman yang berbeda karena merupakan pemukiman yang berdiri di daratan.

Berdasarkan hasil perhitungan dengan menggunakan rumus sampel minimal pada desain kasus kontrol (Lameshow) sebanyak 45 kasus dan 45 kontrol. (Notoadmodjo : 2017).

Metode penarikan sampel yang digunakan adalah consecutive sampling, dimana semua nelayan yang memenuhi kriteria pemilihan dimasukkan dalam penelitian sampai jumlah subjek yang diperlukan dipenuhi. Sedangkan pemilihan kontrol berdasarkan pencocokan (matching) berdasarkan kelompok usia dan lama bekerja sebagai nelayan.

Data primer Data yang di peroleh langsung dari responden melalui wawancara dengan menggunakan pedoman wawancara (kuesioner), 
observasi, mengukur luas lantai, mengukur ventilasi rumah, mengukur kelembapan. Data sekunder adalah data yang diperoleh dari Puskesmas Belawan I, Medan dan Instansi terkait lainnya. Data sekunder digunakan dalam penelitian ini untuk mendukung datadata primer sehingga pembahasan penelitian dapat lebih luas dilakukan.

Analisis data secara univariat dengan melihat distribusi frekuensi, analisis bivariat dilakukan dengan menggunakan uji chi square, dan analisis multivariat dengan menggunakan uji regresi logistik dengan tingkat kepercayaan $95 \%$.

\section{HASIL DAN PEMBAHASAN}

\section{A. Distribusi Karakteristik Nelayan}

Karakteristik Individu Nelayan yang dimaksud dalam penelitian ini yaitu Usia, Masa kerja menjadi nelayan dan Riwayat pekerjaan selain nelayan. Hasil analisis untuk variabel tersebut dapat dilihat pada berikut:

$\begin{array}{rr}\text { Tabel1.Distribusi } & \begin{array}{r}\text { Karakteristik } \\ \text { Nelayan di } \\ \text { Kampung } \\ \text { Nelayan } \\ \text { Lingkungan XI } \\ \text { Belawan I, Medan }\end{array} \text { Kelurahan } \\ \end{array}$

\begin{tabular}{llllcl}
\hline & Karakt & \multicolumn{4}{c}{ Responden } \\
\cline { 3 - 6 } No & eristik & Ka & $(\%)$ & Ko & $(\%)$ \\
$\cdot$ & Individ & su & & ntr & \\
& u & S & \multicolumn{2}{c}{ ol } \\
\hline
\end{tabular}

1. Usia

(thn)

\begin{tabular}{llcccc} 
& $21-30$ & 18 & 20 & 17 & 18,9 \\
$31-40$ & 9 & 10 & 12 & 13,3 \\
$41-50$ & 10 & 11,1 & 10 & 11,1 \\
$>50$ & 8 & 6,7 & 6 & 6,7 \\
\hline & Jml & $\mathbf{4 5}$ & $\mathbf{5 0}$ & $\mathbf{4 5}$ & $\mathbf{5 0}$ \\
\hline 2. & Masa & & & & \\
& Kerja & 14 & 15,6 & 20 & 22,2 \\
& $1-3$ & 12 & 13,3 & 10 & 11,1 \\
& $4-6$ & 8 & 18,9 & 11 & 12,2 \\
& $7-9$ & 11 & 12,2 & 4 & 4,4 \\
& $\geq 10$ & & & & \\
\hline Jml & $\mathbf{4 5}$ & $\mathbf{5 0}$ & $\mathbf{4 5}$ & $\mathbf{5 0}$ \\
\hline 3. & Riwaya & & & & \\
& t Kerja & & & & \\
& & 37 & 41,1 & 24 & 26,7 \\
\hline
\end{tabular}

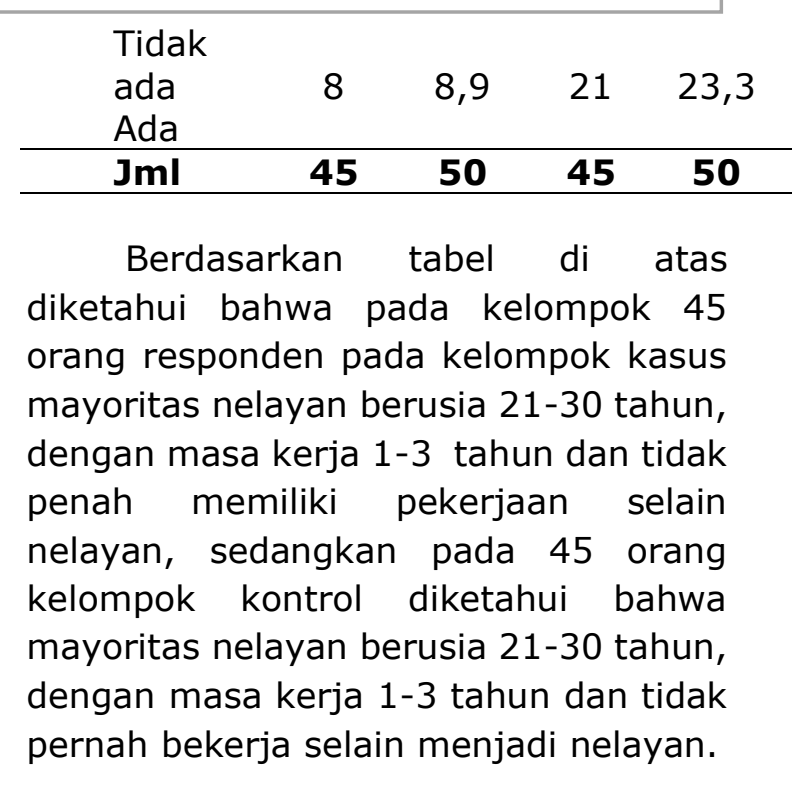

\section{B. Distribusi Variabel Penelitian}

Penilaian Lingkungan Fisik Rumah Nelayan di Kampung Nelayan Seberang Lingkungan XII Kelurahan Belawan I, Medan, diukur dan diobservasi Ventilasi, Suhu, Kelembaban dan Lubang asap dapur, Kepadatan hunian, Bahan bakar yang digunakan untuk memasak, Penggunaan obat nyamuk bakar dan kebiasaan membuka jendela. Hasil analisis untuk variabel terseut dapat dilihat pada berikut:

\section{Tabel2.Distribusi Karakteristik Rumah Nelayan di Kampung Nelayan Seberang Lingkungan XII Kelurahan Belawan I, Medan}

\begin{tabular}{cccccc}
\hline N & Ka & Ko & & Ko \\
o. & su & $(\%)$ & $\begin{array}{c}\text { ntr } \\
\text { ol }\end{array}$ & (\%) \\
\hline
\end{tabular}

1. Ventilasi

\begin{tabular}{lcccc}
$\begin{array}{l}\text { 1. Tidak } \\
\text { memenu } \\
\text { hi syarat }\end{array}$ & 25 & 27,8 & 28 & $\begin{array}{c}58, \\
9\end{array}$ \\
$\begin{array}{l}\text { 2. Memenu } \\
\text { hi syarat }\end{array}$ & 20 & 22,2 & 17 & \\
& & & & $\begin{array}{c}41, \\
1\end{array}$ \\
\hline Total & $\mathbf{4 5}$ & 50 & $\mathbf{4 5}$ & $\mathbf{1 0 0}$
\end{tabular}

2. Suhu

$37 \quad 41,1 \quad 23$




\begin{tabular}{|c|c|c|c|c|c|c|c|c|c|c|c|}
\hline \multirow{2}{*}{\multicolumn{2}{|c|}{$\begin{array}{l}\text { 1. Tidak } \\
\text { memenu } \\
\text { hi syarat } \\
\text { 2. Memenu } \\
\text { hi syarat }\end{array}$}} & \multirow[t]{2}{*}{8} & \multirow[t]{2}{*}{8,9} & \multicolumn{2}{|r|}{$\begin{array}{c}66 \\
7\end{array}$} & \multicolumn{2}{|r|}{$\begin{array}{l}\text { 2. Memenu } \\
\text { hi syarat }\end{array}$} & 10 & 11,1 & 20 & $\begin{array}{c}22, \\
2\end{array}$ \\
\hline & & & & \multicolumn{2}{|r|}{$\begin{array}{c}33 \\
3\end{array}$} & & Total & 45 & 50 & 45 & 50 \\
\hline & Total & 45 & 50 & 45 & & 8. & $\begin{array}{l}\text { Buka } \\
\text { Jendela }\end{array}$ & & & & \\
\hline \multirow{3}{*}{3.} & Kelembab & \multirow{3}{*}{38} & \multirow{3}{*}{42,2} & \multirow{3}{*}{25} & \multirow[b]{2}{*}{70} & & 1. Tidak & 23 & 25,6 & 27 & 30 \\
\hline & 1. Tidak & & & & & & 2. $\mathrm{Ya}$ & 22 & 24,4 & 18 & 20 \\
\hline & memenu & & & & & & Total & 45 & 50 & 45 & 50 \\
\hline
\end{tabular}

2. Memenu hi syarat

\begin{tabular}{lcccc}
\hline Total & $\mathbf{4 5}$ & 50 & $\mathbf{4 5}$ & $\mathbf{1 0 0}$ \\
\hline $\begin{array}{l}\text { 4. Lubang } \\
\text { asap } \\
\text { dapur }\end{array}$ & & & & \\
$\begin{array}{l}\text { 1. Tidak } \\
\text { baik }\end{array}$ & 19 & 21,1 & 12 & 34, \\
2. Baik & 26 & & 33 & 4 \\
& & & & 65 \\
\hline Total & $\mathbf{4 5}$ & 50 & $\mathbf{4 5}$ & $\mathbf{1 0 0}$
\end{tabular}

\section{Kepadatan Hunian}

1. Tidak memenu hi syarat

$22 \quad 24,4 \quad 13 \quad \begin{array}{r}38 \\ 9\end{array}$

2. Memenu hi syarat

$23 \quad 25,6 \quad 32$

$$
61,
$$$$
1
$$

\begin{tabular}{lcccc}
\hline Total & $\mathbf{4 5}$ & 50 & $\mathbf{4 5}$ & $\mathbf{1 0 0}$ \\
\hline $\begin{array}{l}\text { 6. } \\
\text { Bahan } \\
\text { Bakar }\end{array}$ & & & & \\
$\begin{array}{l}\text { 1. Tidak } \\
\text { memenu } \\
\text { hi syarat }\end{array}$ & 34 & 37,8 & 34 & $\begin{array}{c}75, \\
6\end{array}$ \\
$\begin{array}{l}\text { 2. Memenu } \\
\text { hi syarat }\end{array}$ & 11 & 12,2 & 11 & \\
& & & & $\begin{array}{c}24, \\
4\end{array}$ \\
\hline Total & $\mathbf{4 5}$ & 50 & $\mathbf{4 5}$ & $\mathbf{1 0 0}$ \\
\hline
\end{tabular}

7. Obat

Nyamuk

Bakar

1. Tidak memenu $\begin{array}{llll}35 & 38,9 & 25 & 27\end{array}$ hi syarat

$\begin{array}{rrr}35 & 27, \\ & 8\end{array}$

Berdasarkan tabel 4.2 bahwa dapat diketahui bahwa dari 40 rumah yang diobservasi terdapat $23(57,5 \%)$ kondisi ventilasi reponden yang tidak memenuhi syarat dan 17 (42,5\%) yang memiliki kondisi ventilasi responden yang memenuhi syarat. Dari 40 rumah yang diobservasi terdapat $25(62,5 \%)$ kondisi lantai reponden yang tidak memenuhi syarat dan $15(37,5 \%)$ yang memiliki kondisi lantai responden yang memenuhi syarat. Dari 40 rumah yang diobservasi terdapat 23 (57,5\%) kondisi pencahayaan reponden yang tidak memenuhi syarat dan $17(42,5 \%)$ yang memiliki kondisi pencahayaan responden yang memenuhi syarat.

Dan dapat diketahui bahwa dari 40 rumah yang diobservasi terdapat 22 $(55,0 \%)$ kondisi kelembaban reponden yang tidak memenuhi syarat dan 18 $(45,0 \%)$ yang memiliki kondisi kelembaban responden yang memenuhi syarat.

\section{Keadaan Ventilasi}

Keadaan ventilasi merupakan perbandingan antara luas lubang penghawaan dengan luas lantai seluruh ruangan. Lubang penghawaan yang dimaksud adalah seluruh lubang pada dinding rumah yang berfungsi sebagai sarana yang memungkinkan pertukaran udara dari luar ke dalam dan juga sebaliknya. Luasnya saluran penghawaan dalam rumah yang 
permanen minimal $10 \%$ dari luas lantai rumah, dikatakan memenuhi syarat kesehatan apabila ventilasi rumah $\geq 10 \%$ luas lantai, dan tidak memenuhi syarat kesehatan apabila ventilasi rumah tidak ada atau $<10 \%$ luas lantai. (Ferdy, dkk. : 2016).

Hasil penelitian menemukan pada kelompok kasus mayoritas rumah nelayan tidak memenuhi syarat dan pada kelompok kontrol diketahui memiliki karakteristik yang sama yaitu mayoritas ventilasi rumah nelayan tidak memenuhi syarat.

\section{Keadaan Suhu}

Suhu merupakan keadaan udara panas atau dingin suatu waktu yang diperoleh dari hasil pengukuran harian dan dirata-ratakan setiap bulan. Hubungan antara iklim dengan kejadian penyakit bisa terjadi secara langsung maupun tidak langsung.

Menurut Goul dan Brooker dalam Sinaga, L (2014), Mycobacterium tuberculosis merupakan bakteri mesofilik yang tumbuh subur dalam rentang $25-40 \circ \mathrm{C}$, akan tetapi akan tumbuh secara optimal pada suhu 31$37 \circ \mathrm{C}$.

Dikatakan memenuhi syarat apabila suhu berada pada batas kenyamanan suhu yaitu 23 - 270 C, dan tidak memenuhi syarat apabila lebih rendah ataupun lebih tinggi dari suhu nyaman. (Keputuan Menteri Kesehatan RI Nomor 829 : 1999).

Hasil penelitian menunjukkan pada kelompok kasus mayoritas rumah nelayan memiliki suhu yang tidak memenuhi syarat begitu pula yang ditemukan pada rumah nelayan kelompok kontrol.

\section{Keadaan Kelembaban}

Kelembaban adalah kadar uap air dalam ruangan dinyatakan dalam persen (\%). Penentuan dinilai dari besar kelembaban optimum di dalam rumah sesuai dengan ketetapan depkes yaitu 40 - 70\%. Diklasifikasikan baik bila 40
- $70 \%$ dan tidak baik bila $<40 \%$ atau $>70 \%$. (Keputuan Menteri Kesehatan RI Nomor 829 : 1999).

Hasil penelitian menunjukkan mayoritas rumah pada kelompok kasus memiliki kelembaban yang tidak memenuhi syarat begitu pula yang ditemukan pada rumah responden pada kelompok kontrol.

\section{Kondisi Lubang Asap Dapur}

Kondisi keberadaan Lubang asap dapur dalam penelitian ini dinilai dari ada atau tidaknya lubang pengeluaran asap di dapur sehingga tidak terjadi pengepulan asap di dapur. Dikategorikan baik apabila ada lubang asap yang mampu mengeluarkan asap dapur dan tidak terjadi pengepulan asap dapur, dan dikategorikan tidak baik bila tidak ada lubang asap dapur. (Keputuan Menteri Kesehatan RI Nomor 829 : 1999).

Hasil penelitian menunjukkan bahwa mayoritas rumah pada kelompok kasus memiliki lubang asap dapur yang baik begitu pula yang ditemukan pada rumah responden pada kelompok kontrol.

\section{Kepadatan Hunian Rumah}

Tingkat kepadatan hunian rumah dalam penelitian ini dinilai dari rasio luas lantai dengan jumlah penghuni tetap. Padat apabila rasio $<8 \mathrm{~m}^{2} /$ orang dari luas lantai rumah dan tidak padat bila rasio $\geq 8 \mathrm{~m}^{2} /$ orang dari luas lantai rumah. (Keputuan Menteri Kesehatan RI Nomor 829 : 1999).

Hasil penelitian menunjukkan bahwa mayoritas rumah pada kelompok kasus memiliki kepadatan hunian yang memenuhi syarat begitu pula yang ditemukan pada rumah responden pada kelompok kontrol.

\section{Jenis Bahan Bakar Memasak}

Jenis bahan bakar yang digunakan untuk memasak dapat berupa kayu, minyak tanah, gas atau listrik. Dikatakan tidak memenuhi syarat apabila menggunakan kayu bakar atau minyak tanah dan memenuhi syarat 


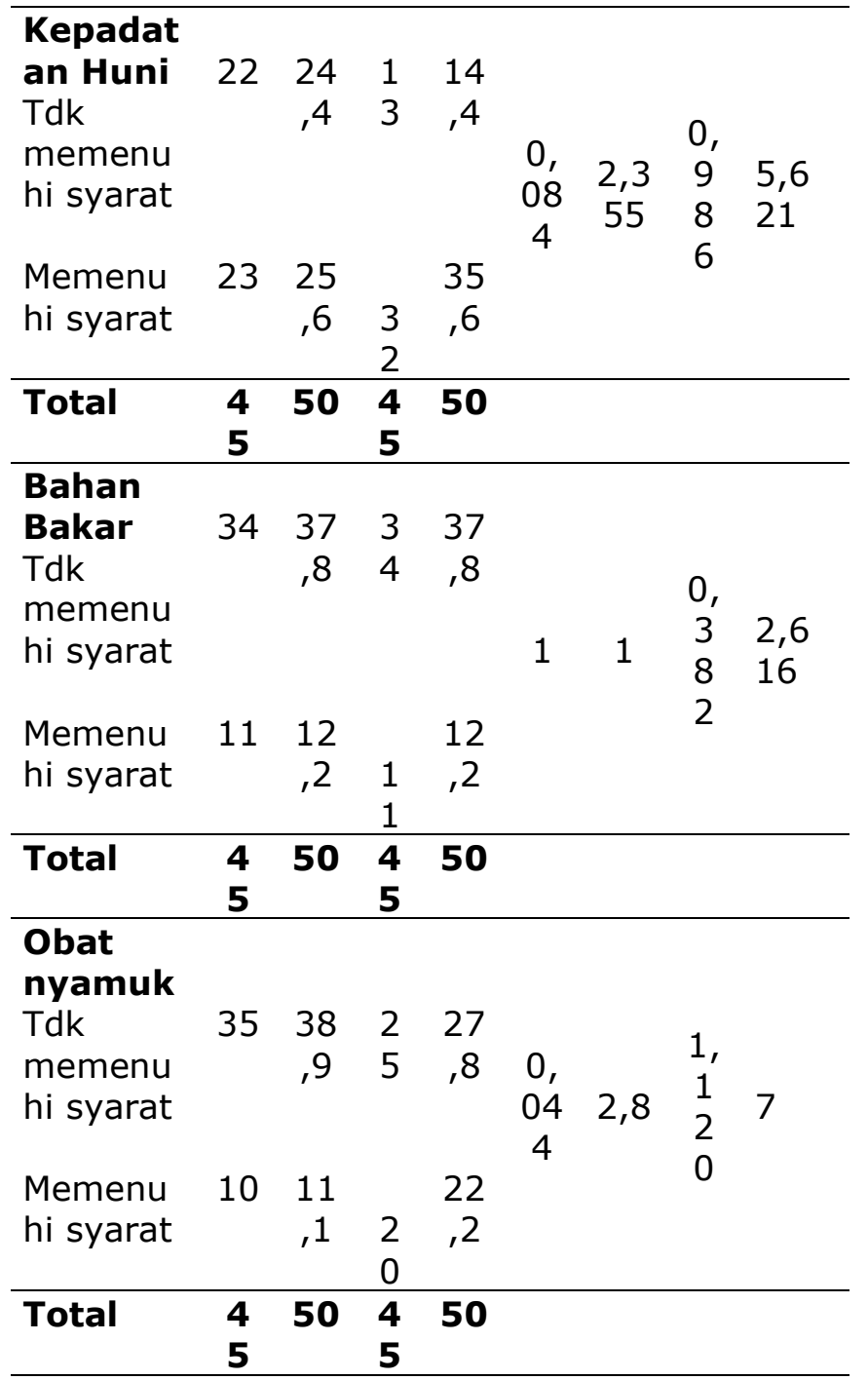

\begin{tabular}{lcccccccc}
\hline $\begin{array}{l}\text { Buka } \\
\text { jendela }\end{array}$ & & & & & & & & \\
Tidak & 23 & 25 & 2 & 30 & 0, & 0,6 & 0, & 1,6 \\
& & 6 & 7 & & 5 & 9 & 3 & 06 \\
Ya & 22 & 24 & & 20 & & 7 & 0 & \\
& & 4 & 1 & & 25 & & 2 & \\
& & & 8 & & & & & \\
\hline Total & $\mathbf{4}$ & $\mathbf{5 0}$ & $\mathbf{4}$ & $\mathbf{5 0}$ & & & & \\
& $\mathbf{5}$ & & $\mathbf{5}$ & & & & & \\
& & & & & & & &
\end{tabular}

\section{Berdasarkan hasil uji tabulasi} silang menggunakan uji chi-square untuk melihat hubungan variabel penelitian dengan kejadian TBC pada Nelayan di Kampung Nelayan Seberang Lingkungan XII, Kelurahan Belawan I, Medan diketahui bahwa variabel yang berhubungan secara statistik dan memiliki nilai $p$-value $>0,005$ yaitu Suhu $(0,004)$, Kelembaban $(0,006)$, dan Penggunaan Obat nyamuk bakar $(0,044)$.

\section{Analisis Multivariat}

Tahap terakhir dari analisis data adalah analisis multivariat. Analisis multivariat digunakan untuk menganalisis pengaruh variabel penelitian terhadap kejadian TBC pada nelayan di kampung nelayan seberang lingkungan XII kelurahan belawan I, Medan digunakan uji regresi logistik berganda (multiple logistic regression).

Analisis multivariat dalam penelitian ini menggunakan uji regresi logistik ganda yaitu salah satu pendekatan model matematis untuk menganalisis pengaruh beberapa variabel independen terhadap variabel dependen kategorik yang bersifat dikotom atau binary dalam model prediksi regresi logistik ganda metode enter.

\section{Tabel 4.Hasil Uji Multivariat Regresi Logistik}

\begin{tabular}{llll}
\hline Variabel & Koe B & $\begin{array}{l}\text { Exp } \\
\text { (B) }\end{array}$ & $\begin{array}{c}\boldsymbol{p} \\
\text { value }\end{array}$ \\
\hline Suhu & 21,647 & 2,519 & 0,999 \\
Kelembaban & 2,128 & 8,4 & 0,083 \\
Penggunaan & - & 0 & 0,999 \\
Obat & 22,135 & 0,123 & 0,002 \\
Nyamuk & -2.093 & & \\
Bakar & & & \\
Constant & & & \\
\hline
\end{tabular}

Dari hasil analisis multivariat di atas diketahui bahwa variabel kelembaban memiliki Nilai Exp (B) yang paling tinggi $=8,4$, sehingga dapat disimpulkan bahwa secara statistik responden yang tinggal di rumah dengan kelembaban yang tidak memenuhi syarat 8,4 kali lebih berisiko mengalami penyakit TBC dibandingkan dengan responden yang tinggal di rumah dengan kelembaban yang memenuhi syarat.

\section{KESIMPULAN}

Berdasarkan uji statistik menunjukkan bahwa terdapat 
1. Variabel Karakteristik Lingkungan yang berhubungan secara statistik dengan Kejadian TBC di Kampung Nelayan Seberang Lingkngan XII Kelurahan Belawan I, Medan yaitu variabel Suhu ( $p$-value : 0,004), Kelembaban ( $p$-value : 0,006) dan Obat nyamuk bakar ( $p$-value : 0,044).

2. Variabel Karakteristik Lingkungan yang tidak berhubungan secara statistik dengan Kejadian TBC di Kampung Nelayan Seberang Lingkngan XII Kelurahan Belawan I, Medan yaitu variabel Ventilasi ( $p$ value : 0,668), Lubang asap dapur ( $p$-value : 0,183), Kepadatan hunian ( $p$-value : 0,084$)$, Bahan bakar ( $p$ value : 1 ) dan Buka jendela ( $p$-value : 0,525).

3. Hasil analisis multivariat di atas diketahui bahwa variabel kelembaban memiliki Nilai Exp (B) yang paling tinggi $=8,4$, sehingga dapat disimpulkan bahwa secara statistik responden yang tinggal di rumah dengan kelembaban yang tidak memenuhi syarat 8,4 kali lebih berisiko mengalami penyakit TBC dibandingkan dengan responden yang tinggal di rumah dengan kelembaban yang memenuhi syarat.

\section{SARAN}

1. Bagi Masyarakat

a. Penggunaan pakaian hangat pada malam hari untuk mengurangi dampak kelembaban rumah yang tinggi.

b. Kebiasan membuka jendela pada siang hari harus lebih ditingkatkan agar sinar matahari dapat masuk sehinga dapat mengurangi kelembaban di dalam rumah dan menurunkan kemungkinan perkembangan mikrobakterium Tuberkulosa di dalam rumah.

2. Bagi Wilayah Kerja Puskesmas Belawan
Diharapkan bagi Puskesmas setempat melaksanakan kebijakan program kesehatan yang telah ditetapkan oleh pemerintah dalam mengurangi angka kejadian Tuberkulosis Paru.

3. Bagi Peneliti Lanjut

Diharapkan bagi peneliti selanjutnya untuk melengkapi hasil penelitian yang telah ada dan mengikuti perkembangan ilmu pengetahuan.

\section{DAFTAR PUSTAKA}

Ahmad, Hudoyo, 2014. Tuberkulosis Mudah Diobati . Jakarta : Fakultas Kedokteran Iniversitas Indonesia

Erwin, Ulinnuha Fahreza, dkk. 2012, Hubungan Antara Kualitas Fisik Rumah dan Kejadian TB Paru Dengan Basil Tahan Asam Positif di Balai Kesehatan Paru Masyrakat. Semarang : Fakultas 


$\begin{array}{lr}\text { Kedokteraan } & \text { Universitas } \\ \text { Muhammadiyah } & \text { Semarang } \\ \text { (Jurnal). } & \end{array}$

Crofton, Jhon,dkk. 2018. Tuberkulosis Klinis. Jakarta : Widya Medika

Depkes RI. 2013, Laporan Hasil Riset Kesehatan Dasar Indonesia Tahun 2013, Badan Penelitian dan Pengembangan Kesehatan,Jakarta.

Departemen Kesehatan. 2010. Republik Indonesia : Pedoman Nasional Penanggulangan Tuberkulosis, Cetakan ke 8, Jakarta.

Dinas Kesehatan Propinsi Sumatera Utara. 2012, Profil Kesehatan PropinsiSumatera Utara.

Dinas Kesehatan Propinsi Sumatera Utara. 2017, Profil Kesehatan PropinsiSumatera Utara.

Ferdy, Ricardo Sinaga, dkk. 2016. Hubungan Kondisi Ventilasi Rumah Dengan Kejadian TB Paru Di Wilayah Puskesmas. Jakarta Direktorat Jendral Bina Upaya Kesehatan (Jurnal).

Harry, S., Kepala Lembaga Demografi Fakultas Ekonomi Indonesia; Ketua Umum Koalisi Kependudukan, 2014. Nelayan dalam Angka, Indonesia (http://nasional.kompas.com/re ad/2014/11/19/21243231/Nela yan.Kita dikutip pada 10 Februari 2015 jam 20.20)

Hutapea, J, 2012. Analisis Faktor Penyebab Pemukiman Kumuh di Kota Medan (Studi Kasus : Kecamatan Medan Belawan), Skripsi, Fakultas Ekonomi Universitas Sumatera Utara, Medan.

Kementerian Kesehatan , 2016. Republik Indonesia : Riset Kesehatan Dasar 2016, Indonesia.

Kementerian Kesehatan, 2014. Republik Indonesia Direktorat Jenderal Pengendalian Penyakit dan
Penyehatan Lingkungan :

Pedoman Nasional Pengendalian Tuberkulosis, Indonesia.

Kementerian Kesehatan, 2011. Republik Indonesia : Pedoman

Penyehatan Udara Dalam Ruang Rumah No. 1077/Menkes/Per/V/2011, Indonesia.

Keputuan Menteri Kesehatan RI Nomor 829 Menkes SK/VII/1999 Tentang Persyaratan Perumahan Sehat. Jakarta.

Linelejan, F, 2012. Gambaran Fungsi Paru, Kebiasaan Merokok dan Kebiasaan Olahraga pada Nelayan di Kelurahan Bitung Karangria Kecamatan Tuminting Kota Manado, Skripsi, Fakultas Kesehatan Masyarakat, Universitas Sam Ratulangi.

Lubis, F, 2010. Gambaran Gangguan Pernapasan pada Nelayan Young Panah Hijau, Skripsi, Fakultas Kesehatan Masyarakat, Universitas Sumatera Utara.

Masriadi, H. 2017, Epidemiologi Penyakit Menular. Depok : PT Rahagrafindo Persada

Ni Made Mertaniasuh,dkk. 2013, Tuberkulosis Diagnostik Mikrobiologis. Surabaya : Airlangga University Press.

Notoatmodjo, Soekidjo. 2017. Metode Penelitian Kesehatan. Jakarta : PT Rineka Cipta

Notoatmodjo, Soekidjo. 2017. Kesehatan Masyarakat IImu, Ilmu dan Seni. Jakarta : PT Rineka Cipta.

Peraturan Menteri Kesehatan Rebuplik Indonesia NO. 1077/MENKES/PER/2011.

Tentang Pedoman Penyehatan Udara Dalam Ruang Rumah. Jakarta:

http//wwwgoogle.com/depkes.g o.id. PMKNNo.client $=1077=$ new. pdf. 
Jurnal Kesehatan Masyarakat \& Gizi, e-ISSN: 2655-0849

Vol. 2 No.1 Edisi Mei-Oktober 2019

https://ejournal.medistra.ac.id/index.php/JKG

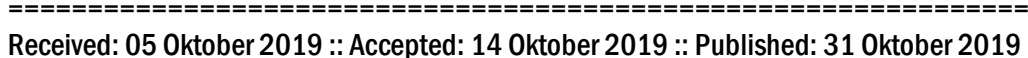

Simanjuntak, I, H, 2014. Morfologi Kampung Nelayan Belawan Medan, Tesis, Fakultas

Teknik Universitas Sumatera Utara, Medan.

Tjandra, Yoga Aditama. 2013. Tuberkulosis, Rokok, Dan Perempuan. Jakarta: Fakultas Kedokteran Universitas Indoensia.

Umakaapa, M., Rahim, M.R, dan Saleh, L. M, 2013. Faktor-faktor yang Berhubungan dengan Gangguan Fungsi Paru pada Pekerja bagian Tekstil CV. BAGABS Kota Makasar, Bagian Kesehatan dan Keselamatan Kerja, Fakultas Kesehatan Masyarakat Universitas Hasanudin, Makassar. 